\title{
VIRTUÁLIS OSZTÁLYTERMI KERETRENDSZEREK ÖSSZEHASONLÍTÁSA
}

Szerzők:

Urbán Dorottya

Eszterházy Károly Egyetem

Chira Csongor

Eszterházy Károly Egyetem

Első szerző e-mail címe:

urbaandorottya@gmail.com

\section{Lektorok:}

Námesztovszki Zsolt $(\mathrm{PhD})$

Újvidéki Egyetem (Szerbia)

Szabó Balogh Ágota $(\mathrm{PhD})$

Gál Ferenc Főiskola

...és további két anonim lektor

\section{Absztrakt}

Az e-learning megjelenése új lehetőségek kapuját nyitotta meg a tanulás és tanítás világába. Korszakunkban, ahol a telekommunikáció és a virtuális tér használta már nem olyan nóvum, melyeket ne lehete értelmezni, már nem jelenthet gondot ezek használata sem. Az okostelefonok, tabletek, számítógépek világában felvetődik a kérdés; hogy hogyan tudnánk a gyerekek kezében lévő tudást integrálni az oktatásba és ez által javukra fordítani? Egy hasznos és jó megközelítése lehet a válaszadásnak, az, ha az online osztálytermi programok felól közelítünk. Tanulmányunkban négy olyan online keretrendszert mutatunk be melyekkel közelebb hozhatjuk az iskolát és az oktatás egészét a tanulókhoz, továbbá bemutatjuk milyen mértékben érvényesül rajtuk keresztül az IPOOmodell.

Kulcsszavak: Online oktatás, Class Dojo, Easyclass, Google Tanterem, Apple Classroom

Diszciplina: pedagógia, pszichológia

\section{Abstract}

\section{A COMPARISON OF VIRTUAL CLASSROOM FRAME SYSTEMS}

The emergence of BYOD and blended learning have opened up entirely new teaching and learning possibilities. We are living in an era where the use of telecommunication and cyberspace (which are not incomprehensible novelties anymore) should not pose a problem. One of the most important questions in the world of smartphones and tablets is how this handheld knowledge can be integrated into education in a way that is beneficial for students. A useful and smart approach is one focusing on online classroom programs. This study discusses four online programs, which can be used to bring school and education itself closer to students, while describing to what extent they adhere to the IPOO model.

Keywords: Online education, online classroom, digital pedagogy, blended learning, Class Dojo, Easyclass, Google Classroom, Apple Classroom

Disciplines: pedagogy, psychology

Urbán Dorottya és Chira Csongor (2019): Virtuális osztálytermi keretrendszerek összehasonlítása. OxIPO - interdiszciplináris tudományos folyóirat, 2019/2, 77-88. doi: 10.35405/OXIPO.2019.2.77 
$\mathrm{Az}$ internet és a telekommunikációs elterjedésével egy olyan digitális környezetet alkottunk magunk köré, melyben az oktatási intézmények tanulóinak más igényei vannak. A tanulás ma már nem csupán az osztályteremben történik, hanem azon kívül is. Erre adnak remek lehetőséget az online osztálytermi platformok, amelyek segítenek összekapcsolni az oktatást és a tanulást az iskolák falain kívül is, ezzel elősegítve a bármikor és bárhol tanulást. Az oktatás új perspektívát nyer ez által. Az egyszerúsített munkafolyamatok révén az oktatók energiája a tanulókra koncentrálódhat így azok konstruktív, személyre szabott feladatokat és visszajelzéseket kaphatnak. Az online tanuló és vizsgázó diákok jobban teljesítenek, mint a hagyományos tantermi környezetben készülők. E tények ösztönöztek minket a népszerúbb virtuális osztálytermi programok bemutatására és összehasonlítására.

A huszonegyedik századra az internetes kommunikáció, valamint a webes jelenlét annyira a hétköznapi élet részévé vált, hogy annak szerepe a tanítási-tanulási folyamatokban is megkerülhetetlen lett. Külföldi és magyar szakirodalmak egyaránt vizsgálják az online tér, azon belül leggyakrabban a közösségi média hétköznapi életre gyakorolt élettani és pszichológiai hatásait, kiemelve annak oktatásban betöltött szerepét is. A terület jellegéből adódóan folyamatosan változó, és a tanítási-tanulási folyamatban résztvevô minden szereplő hétköznapi életét évről évre jobban meghatározó digitális környezet számtalan feladatot és megközelítési lehetôséget ad a témában mélyebben elmerülő kutatóknak. Ezek többsége azonban nem érinti kiemelten az online tantermeket, pedig azok újszerúsége és folyamatos innovativitása tudományos igényű kutatások tárgyát jelenthetnék. Emellett a 2016-ban a köznevelési, a szakeképzési, a felsőoktatási és a felnoöttképzési rendszer digitális átalakitásáról és Magyarország Digitális Oktatási Stratégiájáról is született kormányrendelet, ami szintén csak felületesen érinti kutatásunk tárgykörét.

A pedagógusok és a tanulók is töretlenül szélesebb körben használnak mobil eszközöket és internetes applikációkat. Érthetően adódik a kérdés: miként lehetne ezeket becsatornázni a pedagógiai munkába? Milyen lehetőségeket kínálnak a felhasználóknak a különféle online tantermi alkalmazások? Alkalmasak-e az online tanterem programok az információszerzés és információkezelés különböző fázisainak megszervezésére?

Jelen tanulmány egy rövid elméleti felvezető után négy népszerú virtuális tanterem szolgáltatást nyújtó programot, a Class Dojo-t, az Easyclasst, valamint két multicég, a Google és az Apple osztályterem alkalmazását mutatja be és hasonlítja össze. Az összehasonlítás saját szempontrendszer szerint történik. Összevetjük a platform indulásának évét, az elérhető nyelvek számát, köztük kiemelten a magyar nyelvűséget, a felhasználók számát, tanóra és otthoni alkalmazhatóságát, a szülôi hozzáférést, a tartalmak megoszthatóságát, a tanári visszajelzésekre és értékelésre nyújtott lehetőséget, valamint a programba feltölthető dokumentumok fajtáját, minőségét. Végül értékeljük, milyen mértékben érvényesül az IPOO-modell (Mező, 2011), azaz melyik tanulási stílusok érvényesülnek a különbözó online tantermi alkalmazásokban.

\section{A virtuális osztályterem}

A kutatás megfelelő kontextusba helyezéséhez szükséges bizonyos alapfogalmak jelentését tisztázni. A címben használt online tanterem terminus is ilyen. Gyakran kerülnek említésre rossz formában például digitális, vagy virtuális osztályterem néven, ami okozhat némi félreértést az olvasókban. Az említett fogalmaktól élesen elválasztva online tanterem alatt nem csak a digitális eszközök, mint például okostábla, vagy számítógép, tablet és okostelefon tanítási-tanulási folyamatokba való beépítését értjük, hanem kifejezetten a tantermi oktatást internet alapú platformra transzportáló online alkalmazásokat.

Ezek természetesen elérhetőek a felsorolt eszközökrôl, de nem a hordozó a lényeg, hanem a program. Ilyen értelemben online tanteremnek nevezzük azokat az alkalmazásokat, amik olyan inter netalapú kommunikációs programok, melyek alkalmasak tanárok, diákok és szülők kapcsolattartására, oktatási-tanulási tevékenységek koordinálására, iskolához kapcsolódó konkrét feladatok interaktív megoldására. Fontos szegmens az interaktivitás, és az azonnaliság. Míg a fizikai térben kiépített, digitális táblával és okoseszközökkel ellátott 
tanterem az iskola épületéhez köt, addig ezek tartózkodási helytől és időtól függetlenül elérhetőek.

A tanulmány tanulásszervezési egységével foglalkozó elemző részét az IPOO-modell (Mező, 2011) alapján is végezzük. A modell szerint a tanulást információfeldolgozásként értelmezzük, így az információszerzés és feldolgozás különböző szakaszokra bontható. Ezen szakaszokból tevődik össze a mozaikszó is: információgyújtés (Input), információfeldolgozás (Process), információ alkalmazása és felhasználása $(O u t p u t)$, és az ezek eredményességét nagyban meghatározó tanulásés oktatárszervezés (Organization).

\section{Történetiség-kontextus}

A web 2.0 újdonságai a hétköznapi élet átalakítása mellett az oktatás számára is új színtereket nyitnak meg. A közösségi média legfontosabb jellemzői, a tartalommegosztás és az interaktivitás a tanítás-tanulás során is fontos lehetôségeket nyújtanak. A 2000-es évek generációja azon a technológián nőnek fel, amit a szüleik is ismernek, viszont velük ellentétben ők már beleszülettek ebbe a technikai környezetbe, így sokkal könnyebben alakítják kompetenciává elméleti és használati tudásukat (Tari, 2011.) Marc Prensky ezeket a fiatalokat digitális bennszülötteknek nevezi, akik egész életüket úgy élték le, hogy számítógépek, televíziók, videójátékok, kamerák, mobiltelefonok és a digitális kor egyéb vívmányai vették körül őket, ezért már „anyanyelvi szinten” beszélik az internet digitális nyelvét. Ezekből következik, hogy a mai diákok másképp is gondolkodnak a világról, másképp dolgozzák fel a környezetükből érkező információkat, mint szüleik, vagy tanáraik. Nem feltétlenül velük szemben, de szinte biztosan az ő világukon kívül helyezkednek el a digitális bevándorlók. (Prensky 2001.) Ök azok, akiknek még idegen az internet világa, és ha információra van szükségük nem az internet az első gondolatuk, ahonnan azt az információt beszerezhetik. Prensky szerint az oktatás mai problémái közül az egyik legfontosabb, hogy nagyon sok a digitális bevándorló tanár, akik más nyelvet beszélnek, mint megváltozott tanítványaik, akik már nem azok, akikre a módszereiket kitalálták, és akikre az oktatási rendszert tervezték. A ma diákjai már hozzá vannak szokva, hogy az információkhoz gyorsan hozzá tudnak jutni, szeretnek egyszerre több mindennel foglalkozni, jobban kedvelik az ábrákat, képeket, mint a hosszú szövegeket, valamint igénylik az azonnali visszajelzéseket, megerősítéseket. Ezekhez egyértelmúen a digitális világ szoktatta őket, ebbe a világba illeszkedhet az online tantermek által kínált tanulási tér.

\section{Lehetöségek}

Az internet rugalmassága, könnyen kezelhetősége és gyorsasága miatt ideális terep az oktatás számára. Az online tantermek segítségével a diákok aktívan, kooperatívan tudnak részt venni saját, és egymás tanulási folyamataiban. Ezeken a felületeken a munka nem tanárközpontú, hanem a csoporton, osztályon van a hangsúly, így adott a lehetőség, hogy aktívan, kreatívan vegyenek részt a tanulás folyamatában.

Ha megfelelően használják, az online térnek rengeteg előnye lehet az oktatási környezetben. Eleve plusz motivációt adhat a fiataloknak, hogy saját digitális környezetükbe csempészik be az iskola világát. Ezzel együtt azonban nem magától értetődő, hogy az internet előnyei automatikusan előkerülnek. Az önmagában nem biztos, hogy elég, hogy létrehoznak a közösségi médiában egy osztály csoportot, vagy osztály blogot, amire a diákokat csak úgy ráengedik. A Canberrai Egyetemen tanárképzéssel foglalkozó Magen Poore a digitális környezetben zajló tanításra készíti fel tanárjelöltjeit (Poore, 2015). Hogyan használjuk a közösségi médiát az oktatásban? címú múvében az online média nagy platformjainak (pl. blogok, wikik, közösségi oldalak) oktatásban használható lehetőségeit mutatja be. Poore a lehetőségek mellett kitér a közösségi média jelentette veszélyekre, illetve négy nagy kategóriát említ, melyeken belül további készségfejlesztési lehetőségeket ajánl az információfeldolgozásra. Az általa felállított szempontok szerint is megvizsgáltuk az online tantermi alkalmazásokat.

Az intellektuális elönyökkel kezdjük a felsorolást, közöttük az elemzés, értelmezés, szintézis, kritika négyesével. Az online tantermek lehetőséget adnak a bemeneti információ felbontására, sémák és jellemzők felismerésére, majd újbóli összeállitására, hogy végül új, vagy más jelentést adjanak neki. Általános előnye 
ezeknek a programoknak, hogy a megerősítés, minősítés, kiértékelés hármasra azonnal és közvetlenül felületet biztosít.

Az intellektuális előnyök után a kommunikáció, az együttmüködés, a részuétel és szocializáció területén kiaknázható lehetőségeket vesszük sorra. Ezek közül legegyértelmúbb a kommunikáció terén megmutatkozó előnye, hiszen az online tantermekhez regisztrációs lehetőségként felkínált közösségi média eleve azért jött létre, hogy kommunikáljanak, kapcsolatot tartsanak, párbeszédeket folytassanak ezen keresztül. Közösségi jellegéből adódó pozitívuma jelentkezhet az együttműködés és a csapatmunka terén. Ha a tanár jól irányítja a folyamatokat, az online tantermekben a feladatokat együttműködve, közösen végezhetik a tanulók.

Ehhez szorosan kapcsolódik a részvétel lehetősége, hiszen a kooperáció csak úgy képzelhetô el, ha abban mindenki lehetôséget kap a részvételre. Az online tantermek egyik legizgalmasabb előnye ez, hiszen szakítva a tanulás egyéni jellegével, sokféle lehetôség nyilik a közös munkára, amiben mindenki részt vehet, és az elért eredmények, sikerek öröme is közösen megélhető élménnyé válik.

Harmadikként a motivációs elónyöket vizsgáljuk. Ennek alapja az a tapasztalat, hogy a fiatalok a szabadidejük jelentős részét a közösségi média világában töltik, és az a tény, hogy ez a világ számukra ennyire vonzó, az iskolai munkában is becsatornázható. Első motivációs elôny lehet az irányítás és a tulajdonlás. A diákok saját maguk hozhatják létre felületeiket a digitális tantermekben, saját képükre alakíthatják azt és saját tartalmaikkal tölthetik meg. A tanteremből kilépve nagyobb igyekezetre ösztönözheti őket, ha tudják, hogy munkájuk nyilvános és mások is megnézik. Motiválhatja ôket, ha munkájukat nem csak a tanáruk véleményezi, hanem a csoporttársak is. Önbizalmat adhat, ha akár nagyobb közönségtől kapnak pozitív visszajelzést. Külön motiváló, hogy kreativitásuknak is helyet biztosít a közösségi média, nyilvánossá tehetik az online tanteremben alkotott saját kreatív produktumaikat, videóikat, vagy szövegeiket.

Végül a menedżsment-és adminisz̨rativ elönyökkeel zárjuk az általános elemző szempontrendszereket bemutató felsorolást. Az online tantermi programok az oktatási előnyök között a pedagógiai munkával járó szervezési és irányítási feladatok elvégzésében is segitséget nyújthatnak. Először is könnyú és azonnali visszajelzést biztosít. A legtöbb alkalmazás rendelkezik komment funkcióval. Ezeken keresztül, aki látja az adott produktumot, azonnal tud reagálni is arra. Az online tantermekben a dokumentumok visszakereshetők, a szerkesztési folyamatok nyomon követhetők, így a tanár könnyedén közbe tud avatkozni, ha valami problémát észlel. Fontos, hogy ezek az alkalmazások az iskolákon kívül is elérhetôk. Így a tanár-tanár, tanár-diák és a tanár-szülő kommunikációhoz nem kell az intézmény falai között tartózkodni. A szülők számára is lehetőség, mert gyors és közvetlen kapcsolat alakítható ki az iskolával, és a tanárral. Ha nyilvános egy tanterem, vagy szüló is tagja a csoportnak, ahol a munka zajlik, akkor még a diákok közös projektjeinek alakulását is nyomon tudják követni. Nagy előnye az is, hogy a diákok azonnal beadhatják egyéni munkáikat is, nem kell azt kinyomtatni és papír alapon beadni (Poore, 2015).

A számos előny összegzéseként elmondható, hogy az aktív és közösségi tanulás élménye nemcsak korszerúbb, de eredményesebb, ha azt a tanár megfelelő kontroll alatt tudja tartani. Az együttműködő, interaktív folyamat során a tudást és a jelentést tapasztalatok révén szerzi a diák, és az így szerzett tudás sokkal jobban be tud épülni és használhatóbbá, könnyebben elôhívhatóvá válik.

\section{Fejlesztési javaslatok}

Az online tanterem alkalmazások még a digitális pedagógia területén is újszerú szakaszban vannak. A vizsgált alkalmazások közül a legrégebbi Class Dojo is még csak hét éve érhető el. Népszerűségük azonban folyamatosan növekszik, elemzésünk idején a vizsgált alkalmazások felhasználóinak száma többszázmillió. Ennek ellenére hazánkban az online tantermekkel szemben sokkal népszerúbbek a közösségi oldalak. Hiába a sok edukációs célra kifejlesztett online közösségi tér, a legtöbben valamelyik közösségi oldalon (főleg Facebookon) szerveznek iskolai tematikájú csoportokat.

Az online tantermek lehetnének az igazi alternatívái a Facebookon múködő osztály-csoportoknak. Itt tag 
lehet minden osztályba járó diák és tanár, megoszthatók a feladatok és a szervezési munkák is átláthatóan, jól strukturálhatóan és visszakereshetően végezhetők. Ezzel kiküszöbölhető lehetne a Facebook szervezési szempontokból élvezett előnye, de ehhez a digitális pedagógusnak is ismerniük kellene a felületeket, hiszen csak úgy ösztönözhetôk a tanulók arra, hogy inkább ezeket a programokat használják a közösségi média helyett. Az online tér nyújtotta lehetőségek ismertetése a pedagógusképzés részét kellene képezze, hogy azok hatékonysága maximalizálható legyen.

\section{Az. online tantermi programok és az. IPOO-modell}

Az IPOO-modell (Mező, 2011) tanulásszervező, információszerző és feldolgozó fázisai megjelennek az online tantermi programok vizsgálata során. A programok mind használhatók információszerző forrásként (Input). A különböző felületeken a tanár jelen lehet információközlő ágensként, de lehet mentor szerepben is, aki csak ellenőrzi a tanulók közösen elóállított, szerkesztett és felhasznált adatbázist.

Az alkalmazások teret adnak az információk feldolgozásának is (Process). Az online tér ezen felületei alkalmas tanulási térnek tekinthetôk, ahol a diák a meglévő információk feldolgozását elvégezheti. A direkt tanulás és a tananyag feldolgozása mellett a vizsgált tantermi programok lehetőséget biztosítanak múveltetô feladatok elvégzésére is. A tanárnak lehetősége van teszteket, kreatív feladatokat készíteni a tanulók számára, amik akár információelóállítással is járhatnak, így a tanulási folyamat produktívvá tud válni.

A fentiekhez szorosan kapcsolható az információk alkalmazása és felhasználása (Output). Az elsajátított tudás ellenőrizhető és mérhető a vizsgált programok mindegyikében. Online tesztek, quizek vagy akár dolgozatok is készíthetôk az alkalmazások segítségével. A programok előnye, hogy a hagyományos számonkérési módszerekhez képest kevesebb stresszel és ösztönzőbb feladatokkal, de akár ugyanolyan hatékonysággal ellenőrizhető az elsajátított tudás.

Ezek az online terek a keretét biztosítják a tanár szervező tevékenységének (Organisation). A pedagógus az alkalmazásokon keresztül tudja kézben tartani és szervezni a tanulási folyamatokat, naprakész tud lenni a feladatok aktuális állapotával, a diákok aktivitásával kapcsolatban. A tanulás mellett egyéb, csoportszervező feladatok elvégzésére is alkalmasak a vizsgált programok.

\section{Online tantermi programok}

\section{Class Dojo}

A Class Dojo, olyan online kommunikációs alkalmazás, mely lehetôvé teszi a tanárok, szülők és diákok közötti állandó kapcsolattartást. Az alkalmazás segítségével napközben bárikor megoszthatnak egymással különböző tartalmakat (fényképeket, videókat, dokumentumokat, megjegyzéseket, osztályzatokat). A Class Dojo fejlesztői csapatokban dolgoznak, ezáltal könynyedén oszthatják meg egymással, tapasztalatiakat, ötleteiket, a fejlesztők 20\%-a maga is fó állású tanár. A vállalat 2011-ben kezdte meg múködését és mára az Amerikai Egyesült Államok K-8 típusú iskolái 90\%ban használják alkalmazásukat. 35 nyelvre fordították eddig le, azonban még magyarul nem érhetô el, viszont így is 700 millió gyereket érnek el világszerte. Használható számítógépen és letölthető okoseszközökre is ingyenesen. Széleskörû elehetőséget és megosztási lehetőséget biztosít. A tanulók kitüntetéseket szerezhetnek, ezeket és érdemjegyeiket, az alkalmazáson keresztül megoszthatják Facebookon, Twitteren vagy Instagramon is. Az online tantermek kialakítása teljesen személyre szabható, különböző kiegészítők tölthetők le hozzá, melyekkel más-más hangulatot lehet elérni. Az osztályteremben minden tantárgyat külön lehet kezelni-létrehozni. A tanulók választhatnak egy-egy avatárt, ami ôket képviseli az osztályteremben, ugyanígy a szülők is. A szülő és a diák avatárja összeköttetésben áll, így a szülő azonnali értesítést kap, ha gyermeke valamilyen jelvényt szerzett. Az alkalmazás használható valósidőben is, a tanitási órán és tanár egyszerre láthatja az összes tanuló avatárját és különféle pozitív és negatív jelvényeket adhat nekik:

- Pozitivi jelvények: szép munka, jó csapatjátékos, helyes megfejtés, +1 pont és gyakorlatilag bármi, amit szeretnénk, ugyanis ezeket a tanár szabadon állíthatja össze. 
- Negativ jelvények: nincs kész a házi feladat, beszélgetsz az órán, otthon felejtett taneszköz.

Minden jelvénynek saját képe van és annak értékét (+/- hány pontot ér) a tanár határozza meg. A kiosztott jelvényekkel feláll egyfajta hierarchia az virtuális osztályban és nyomon követhetô a tanuló teljesítménye \%-ban naponként, vagy akár nagyobb egységekben is. Automatikus diagrammos kimutatást az alkalmazás, mely kiválóan használható akár szülői értekezleten vagy a tanórán motivációként is. Ezen felül a rendszer rendelkezik egy eszköztárral mellyen keresztül a tanárnak lehetóége nyílik a tanulóka, csoportba rendezni, véletlenszerűen kisorsolni valakit az elvégzendő feladatra, időt mérni, utasításokat adni, valamit információkat megosztani a szülőkkel (lásd: 1. ábra).

\section{Easyclass}

Az Easyclass, olyan Learning Management System (LMS), amely lehetővé teszi az oktatók számára, hogy digitális osztályokat hozzanak létre, amelyek révén a tananyagokat online tárolhatják. Továbbá szabadon hozzáférhetnek az elóre elkészített feladataikhoz, kvízeikhez és vizsgáikhoz. A tantárgyakat külön tudják kezelni, emellett figyelemmel kísérhetik a határidőket, eredményeket, továbbá biztosítja, hogy a hallgatók azonnali vagy gyors visszajelzését kapjanak munkáikra, melyeket egy helyen elérhetnek. Eszközeik új lehetőségeket kínálnak az oktatóknak a különböző tevékenységekben való részvételre, és új dimenziót nyitnak az interakció és a hatékony tanulás számára. A vállalat 2013 szeptemberében kezdte meg múködését, robbanásszerűen terjedt az egyetemisták körében és egy év alatt elétre a 220 ezres felhasználóikört, már több mint 800000 aktív oktató és diák használja. A szolgáltatás jelenleg tíz nyelven elérhetô és teljesen ingyenes, a fejlesztők elmondása szerint ingyenes is marad.

A szoftvert fejlesztő csapat tagjai: Olaszország, Magyarország, Románia, USA, Egyesült Királyság, Svájc, Franciaország, Törökország, Szaúd-Arábia és Libanon területérôl dolgoznak. Ez a fajta diverzifikáció lehetővé teszi, hogy nagyobb rálátást nyerjenek a globális tanulási közösségek igényeire.

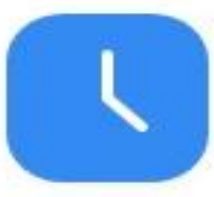

Timer

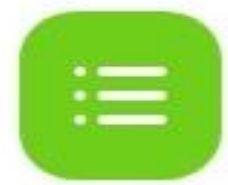

Directions

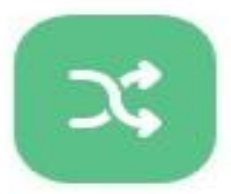

Random

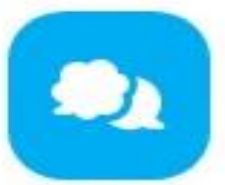

Think Pair Share

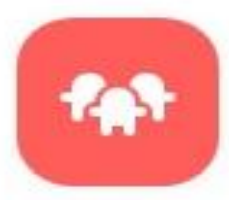

Group Maker

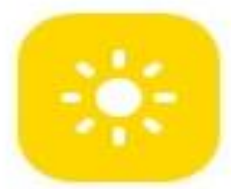

Today

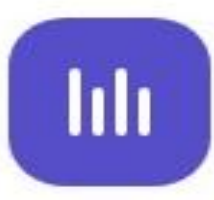

Noise Meter

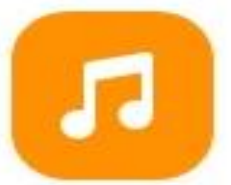

Music 
Az Easyclass összefúzi a diákokat, az oktatókat, a feltöltött tananyagokat, a feladatok és beadandók ellenôrzését, az online teszteket, a naptárba integrált közös teendőket és a vitalehetőségeket.

Mindemellett lehetőséget nyújt az online kapcsolattartásra és telefonos elérhetôségre is. Leegyszerúsítve, legjobban a közösségi média és az online kurzusok ötvözetére hasonlít.

Az Easyclass múködése: az oktatónak lehetősége van létrehozni, különböző tantárgyakat/courses az online osztálytermen belül, melyeket feltölthet saját tartalmaival a my files fülecske alá (dokumentumok, prezentációk, képek, hanganyagok), amikhez a diákok szabad hozzáférést kapnak. A feltöltött tartalmak alá megjegyzéseket is írhatnak, ezzel létrehozva mintegy interaktív üzenőfalat, fórumot. Külön fül alatt találhatóak a beadott a feladatok/assignments, melyek osztályozása és szöveges értékelése is online történek. Az itt kapott pontszámok automatikusan bekerülnek a naplóba/gradebook és nyilvánossá válnak az osztálykö- zösség számára, azonban az osztályzat mellé járó szöveges értékelést csak az érintett diák látja. A platformba alapértelmezett kvíz/teszt program van integrálva a kvízek/quizzes fülecskébe, ennek segítségével az oktató könnyedén készíthet ellenőrző feladatsorokat, akár képekkel ellátva. A válaszadás után a tanuló azonnali visszajelzést kap teljesítményéről, melynek pontszámbeli értéke megjelenik a naplóban.

A naptár/calendar menüpont segítségével összességében láthatják a diákok, hogy mi vár rájuk a következő napokban, hetekben, hónapokban. Az oktató tölti ki, jelöli meg a teendőket az alkalmazást pedig értesítést küldd a diákoknak a közelgő „eseményről”. Továbbá fontos még megjeleníteni az üzenófal/ class wall fülecskét, ahol képeket, dokumentumokat, videókat és szöveges bejegyzéskét tehetnek közzé a diákok és az oktató is, ezzel remek lehetőséget biztosítva akár a kirándulásokon, közös programokon készült élmények megosztására vagy az esetleges kérdéseik megbeszélésére (lásd: 2. ábra).

2. ábra: Az easyclass számítógépes kez̨elófelülete (forrás: easyclass)

\section{easyclass Home Courses Groups MyFiles Inbox}

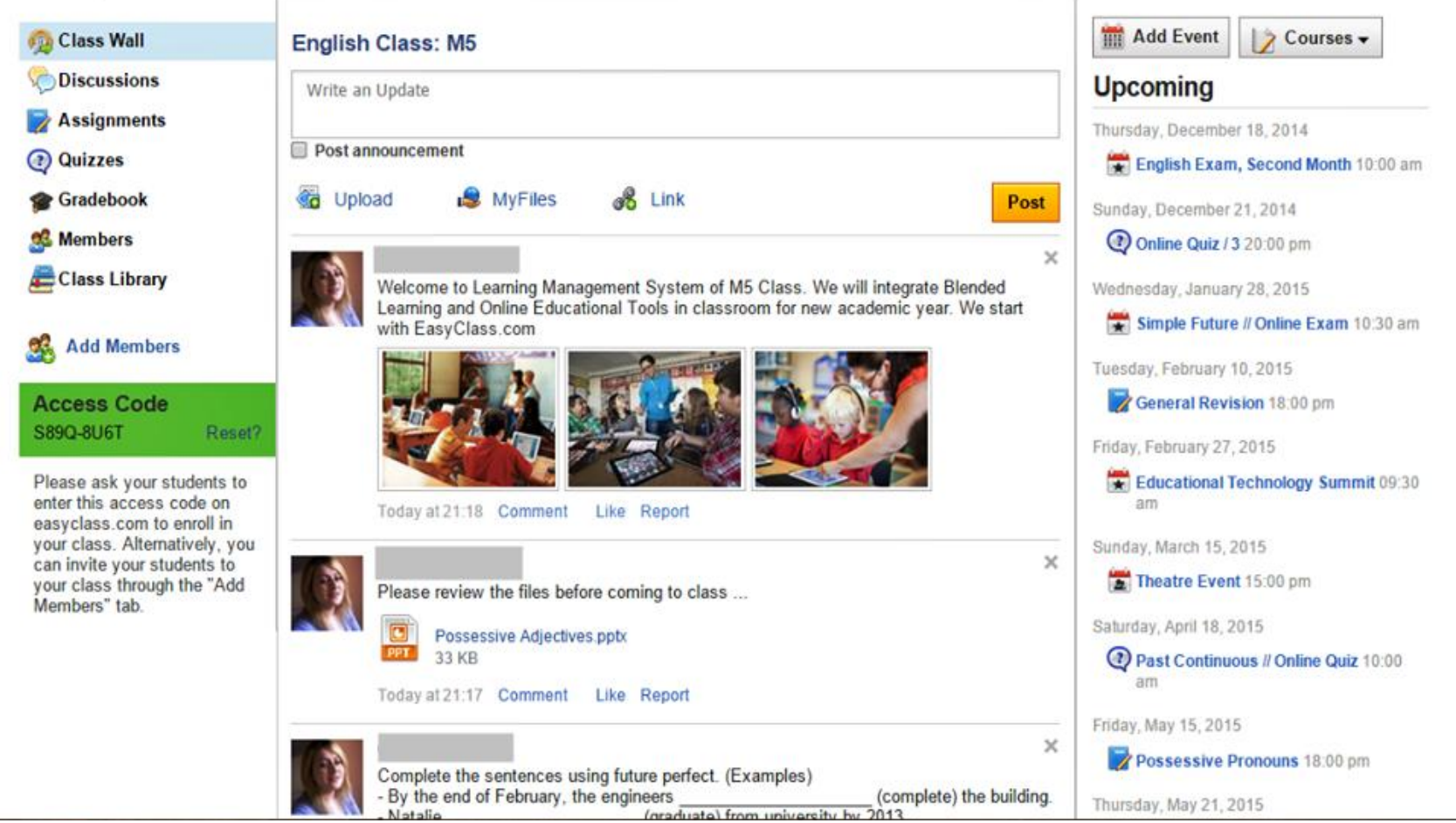




\section{Google Tanterem}

A Google Tanterem egy ingyenes internetes szolgáltatás az iskoláknak, tanároknak és tanulóknak, mely eléréséhez csupán Google-fiókra van szükség. A Tanterem megkönnyíti a tanulók és az oktatók számára az iskolákon belüli és kívüli kapcsolattartást. 2014 májusában kezdte meg múködését a $\mathrm{G}$ Suit-on belül és mára már több mint 70 millió felhasználója van világszerte. A Google fiókbeállításában 150 nyelv közül választhatunk, melyek bármelyikén tudjuk használni a Tanterem alkalmazást, többek közt magyar nyelven is. 2018. augusztus 7-én a Google bejelentette a Google Tanterem frissítését, mellyel javították a felületet minőségét és lehetôvé tették az osztályok más osztályokból való újra felhasználását, valamint a tanárok számára a tartalom témakör szerinti rendezését. (Google, 2018) Továbbá olyan új funkciók jelentek meg, mint például:

- A teendók - Az oldalon a tanárok áttekinthetik a diákok összes munkáját. A felület külön fül alatt kezeli az ellenőrizendó és javított feladatokat.

- A diákok láthatják a kijelölt és befejezett munkáikat minden osztályban.

- Osztályadatok szerkesztése - A tanárok szerkeszthetik az osztályleírást, szakaszt, tárgyat és szobát a beállitások menüpont alatt.

Az eszközcsomag célja a pedagógusok és a diákok képzése. A virtuális tanteremben az oktatóknak lehetőségük van osztályok létrehozására, feladatok kiosztására, osztályozni és visszajelzést küldeni. Bármely böngészővel, például a Google Chrome, a Firefox, az Internet Explorer vagy a Safari segítségével elérhetók az osztálytermek az interneten keresztül. Továbbá 2015től Android és Apple mobil eszközökre is letölthető az alkalmazás, így diákok bármelyen eszközön bejelentkezhetnek a feladataik elvégzéséhez, a tananyagokok letöltéséhez és a visszajelzések megtekintéséhez. A pedagógusok így könnyedén nyomon követhetik a hallgatók fejlődését. A Tanteremben a tanárok akár közösen is kioszthatják a napi feladatokat, ugyanis egy-egy osztályhoz több oktató is rendelhető ezzel megkönnyítve a kommunikációt és az együttmúködést.
A Google Tanterem a fentebb említett számos hasznos funkció mellett:

- segítséget nyújt az adminisztratív feladatok hatékonyabb kezelésében

- költségek nélküli tanulási menedzsmentet biztosít

- lehetôvé tesz, hogy a munka bárhol és bármikor, bármilyen eszközön elvégezhető legyen (Google Classroom, 2018)

Az oktató által jóváhagyott alkalmazások tömegesen integrálódnak az Tanterembe. Ezek az alkalmazások végtelen lehetőségeket kínálnak a kreatív tanuláshoz.

A Google Tanterem használata: belépéskor három lehetőség közül választhatunk: jelentkezés egy osztályba, saját osztály létrehozása vagy belépés a már meglévő osztályunkba. Ha a saját osztályba való belépést választjuk, akkor további három fülből választhatunk: fal, feladatok és személyek. Továbbá a megjelenő fôoldalon tudunk hozzájutni a: teendő, naptár, osztályok és beállitások menüponthoz valamit itt tudunk alkalmazásokat integrálni a felületre is. Bal oldalt, pedig a közelgó négyzetben, azok a feladatok jelennek meg, melyeket a naptárban előre jegyeztünk vagy az beadandók, amiket tanulók beküldtek (lásd: 3 . ábra).

A fal fül felelős az osztálytermi kommunikációért. Itt tudják kommentálni a tanulók az oktató által feltöltött tartalmakat, itt jelennek meg azok a kérdések és szavazások is melyeket szintén az oktató tett közzé, de a tanulók is hozhatnak létre saját bejegyzéseket.

A bejegyzések tartalma lehet szöveg, fájl (dokumentum, prezentáció, kép), videó vagy link. A feladatok fül alatt tud különböző tartalmak létrehozni a tanár egyénre szabottan vagy akár az egész osztály részére. A feladat lehet konkrét feladat, kérdéssor vagy tananyag, ezeket a tartalmakat pedig témakörönként lehet rendezni.

A sz̧emébyek fülben tud hozzárendelni még tanárokat az osztályhoz, valamint itt tudja felvenni a diákokat is e-mail cím alapján.

A beállitásokban folyamatosan szerkeszthetők az osztály adatai, valamit itt található az osztály kódja is, ami egy hét karakterből álló betû és számkombináció, a- 
3. ábra: Google Tanterem kę̧elési felülete legördülö menükkel (saját sžerkesztés)

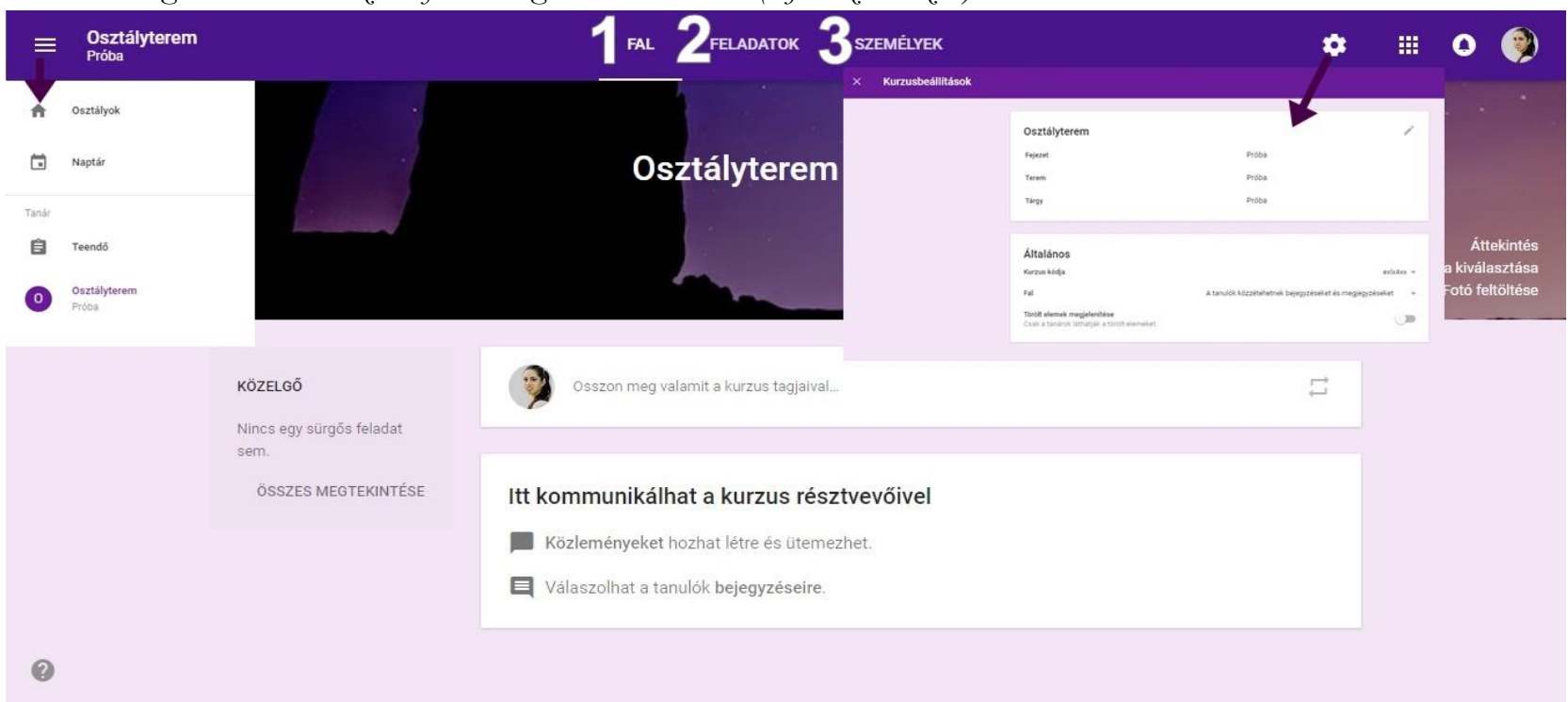

melynek tudatában további tanulók csatlakozhatnak az osztályhoz, így nem szükséges a tanár direkt meghívása.

A naptár az a felület, ahol megjelennek a tanulók feladatai és tanár is figyelemmel tudja kísérni a határidőket.

A teendó-be érkeznek be a tanulók beküldött feladatai, melyek két csoportra osztódnak automatikusan: ellenőrizendő és javított feladatokra. Itt lehetősége nyílik az oktatónak pontokat, osztályzatokat és szöveges értékeléseket adni a leadott munkákra.

Ezen felül lehetőségünk van saját ízlésünkre formálni a főoldalt, a téma kiválasżása pont alatt, ahol választhatunk a Google alapértelmezett képei, mintái közül vagy saját képet is feltölthetünk. A Tanteremben használt össze fájl a Google Drive-on keresztül elérhető és tárolható.

\section{Apple Classroom}

Az osztályteremben az iPad vagy Mac nagy teljesítményú tanári asszisztensré válik, ezzel segítve a tanulók irányítását iPadeken keresztül. A szoftver 2016 márciusában került piacra és 34 nyelven elérhető köztük magyarul is. Az alkalmazás több mint 60 tanulóval tud együttműködni egy osztályon belül. A tanulókhoz a leckék iPaden keresztül jutnak el. Az órán könnyen elindítható ugyanaz az alkalmazás mindegyik hallgató eszközén egyidejűleg, ezzel egyidejűleg másik alkalmazás is indítható diákcsoportok számára. Ezenkívül a tanárok dokumentumokat küldhetnek és fogadhatnak az osztályon belül, és megoszthatják a tanulók munkáját Apple TV segítségével az osztályban, ezáltal akár az órai feladatot is betudják mutatni a diákok. A tanárok azt is láthatják, hogy a tanulók melyik alkalmazást használják éppen, elnémíthatják/lezárhatják a tanulók eszközeit.

Az óra kezdetén a tanulóknak a nevükre kell koppintaniuk az iPaden és bejelentkezni az egyéni jelkódjuk vagy a jelszavuk segítségével, az óra végén pedig kijelentkezni, így egy eszközt több tanuló is használhat. Az adatok Apple ID-vel való bejelentkezés miatt a felhőben tárolhatók így nem okoz gondot, az iPad alap tárhelye és a felhasználóváltás sem. (Apple, 2018)

Az. Apple Osżtályterem basználatának lépései és lehetöségei

A tanórán minden tanulónak rendelkeznie kell iPaddel illetve a tanárnak is. A tanár számára oktatási asszisztensként szolgál a szoftver, ez által könnyedén nyomon követheti is irányíthatja az órát. A tanár által létrehozott osztályterem rendelkezik egy négy számjegyből álló kóddal, melyet beírva csatlakozhatnak a tanulók a virtuális osztályteremhez.

Az alkalmazás megnyitása után lehetőségünk van:

- Weboldal, EPUB-könyv, EPUB-fejezet vagy iTunes megnyitására. Megjegyzés: az EPUB az Electronic Publication angol kifejezés rövi- 
dítése, mely ingyenesen hozzáférhető elektronikus publikációkat jelent..

- Linkek és dokumentumok megosztására, mint a tanár, mint a tanulók részérôl.

- Csoportok létrehozására.

- iPadek zárolására, így a tanulók nem juthatnak információkhoz (hasznos lehet ellenőrző kérdéseknél). A zárolást feloldhatja a tanár vagy automatikusan feloldódik, ahogy az eszköz a Bluetooth-kapcsolat hatótávolságán kívülre kerül.

Az oktató a file képgombból (lásd: 4. ábra) az órai tananyagot fogd és vidd módszerrel az osztályra „húzza”, és pillanatokon belül mindenki eszközén megjelenik az anyag, ezáltal tudják követni a tanárt. Ugyanezzel a technikával tud megosztani minden tanulóval egyszerre, akár weboldalakat vagy egy-egy könyv fejezetet is.

4. ábra: Apple Osztályterem kequelési felülete, a file opcióval kiemelve (forrás: apple)

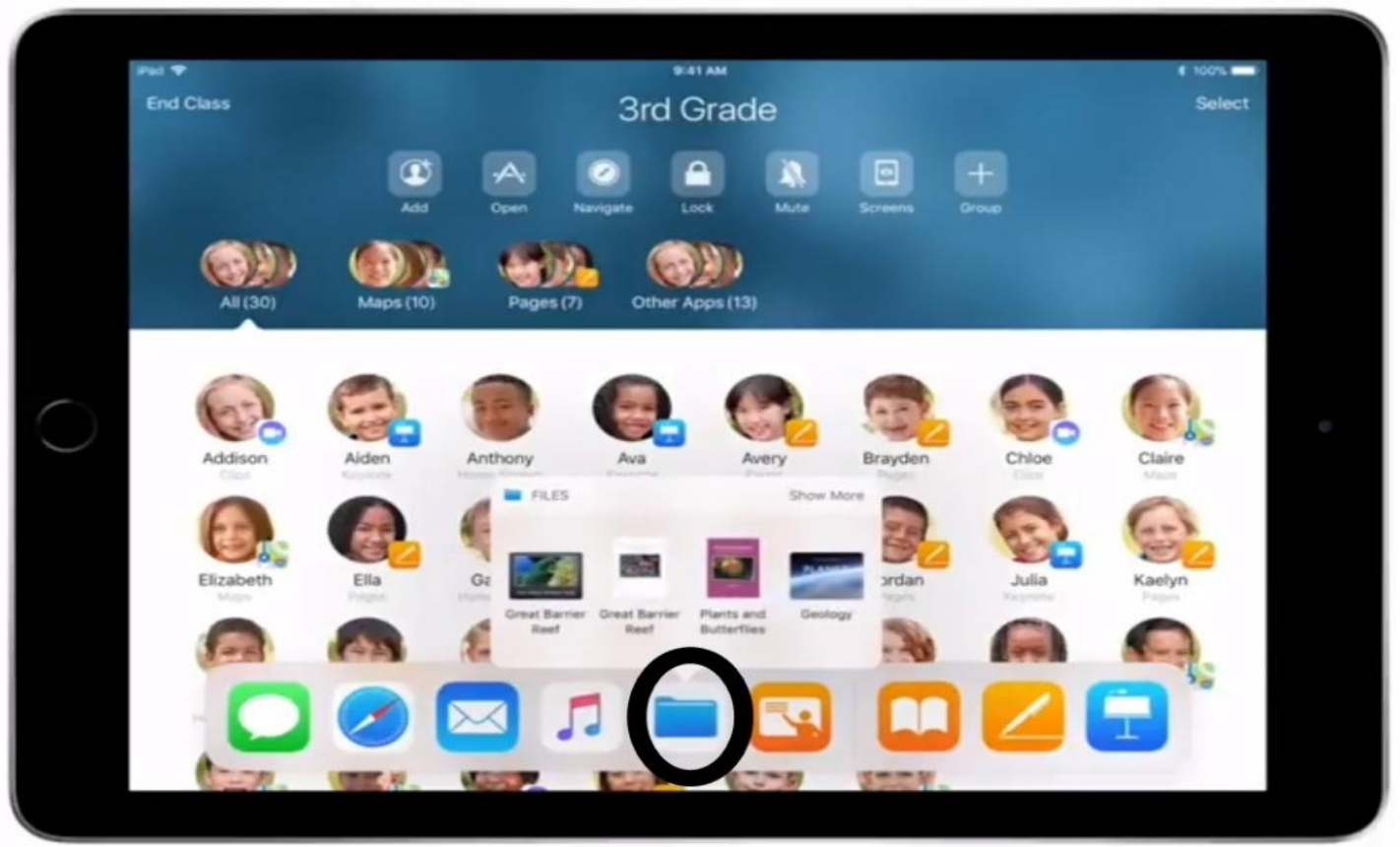

A csoportos munkaforma kialakítása is hasonlóan egyszerü. A group/csoport-ra kattintva új csoportnévvel ellátott csoportok hozhatók létre, melyekben a tanulók behelyezése kijelöléssel történik. A csoportok a feladatok részléteiről és csoporttársaikról szintén tabletjükön értesülnek. A csoportosítás lehetővé teszi a közös munkát így amit az egyik tanuló megcsinál az láthatóvá válik minden csoporttársa számára. Amint elkészültek a csoportok a feladattal értesítés érkezik a tanárnak, illetve a kész munkát is megtudja tekinteni saját eszközén, majd megosztani akár az egész osztállyal. Ez az egyik módja az órán végzett feladatok megosztásának, a másik pedig egy kivetítőn való vetítés. Az óra végén a tanár lezárhatja a lock/ qárolás opcióval a tanulók eszközét ezzel segítve a szünetben a társas kapcsolatok kialakítását.

\section{A Class Dojo, az Easyclass, a Google Tanterem és az Apple Classroom összehasonlítása}

A tanulmányban négy alapjaiban hasonló, ám részleteiben és megvalósulásában különböző online osztálytermi programot vizsgáltunk. A legfontosabb különbségnek a felhasználás módját látjuk. Ugyanis még a Class Dojo lehetőséget nyújt a szülőkkel való kapcsolattartásra - ha osztályzatot, pontot vagy éppen fi- 
gyelmeztetést kapott a tanuló, a szülő telefonján megjelenik az értesítés - addig az említett három program nem. Az Easyclass mind egy kellemes ötvözete a közösségi médiának és az online kurzusok világának. A tanulók szabadon mozoghatnak, kommunikálhatnak az online tér adta lehetőségekben, azonban feladataik elvégzésére is adekvát problémamegoldást biztosít a rendszer. Az Apple és Google fejlesztésében csak a név - tanterem vagy classroom -közös, ugyanis a két program teljesen különböző megközelítésből segíti a tanulást. A Google Tanterem a maga egyszerú, bevált és jól megszokott kezelhetőségével hamar szimpatikussá válhat az egyéb Google szolgáltatásokat felhasz nálók számára. Gyakorlatilag mind azt, amit eddig külön érhettünk el, a kérdőíveket; feladatokat; fáljok létrehozását és tárolását most mind egy fül alatt tudjuk kezelni és megosztani a tanulókkal. A feltöltött feladatokra a tanulók reflektálhatnak, a tanár pedig le tudja osztályozni a beküldött munkákat. Talán ez a program hasonlít legjobban a Easyclasshoz. Az Apple Classroom azoban, sem a szülóknek, sem a tanulóknak nem ad állandó tájékoztatást a diákok jelenlegi tanulmányi állapotáról. A program hasznossága az órai alkalmazás mibenlétében rejlik. Az Apple Classroom, ugyanis tanítási asszisztensként könnyíti meg a tanárok munkáját és teszi interaktívvá az órai munkát a diákok számára. Felhasználása kizárólag iPaden valósulhat meg, a tanár a diákok tabletjére küldött információk alapján tartja meg az órát, ami komoly akadályt jelenthet.

Az 1. táblázatban összegeztük a még lényeges hasonlóságokat és különbségeket.

Mind a négy segíti és támogatja és színesebbé teszi az oktatást, mind a tanárok, mind a diákok számára. Alkalmazásuk hozzájárul a tanulók világnézetének kialakításához.

1. táblázat: Online tantermi programok összehasonlitása (forrás: saját szerkesztés)

\begin{tabular}{|c|c|c|c|c|}
\hline Program neve & Class Dojo & Easyclass & $\begin{array}{r}\text { Google } \\
\text { Tanterem }\end{array}$ & $\begin{array}{r}\text { Apple } \\
\text { Classroom }\end{array}$ \\
\hline Létrehozás & 2011 & 2013 & 2014 & 2016 \\
\hline Elérhető nyelvek száma & 35 & 10 & 150 & 34 \\
\hline Magyar nyelv & $\mathrm{x}$ & $\mathrm{x}$ & $\sqrt{ }$ & $\sqrt{ }$ \\
\hline Felhasználók száma & 700 millió & 800000 & 70 millió & nincs adat \\
\hline Tanórai alkalmazásra alkalmas & $\sqrt{ }$ & $\sqrt{ }$ & $\sqrt{ }$ & $\sqrt{ }$ \\
\hline Otthoni alkalmazásra alkalmas & $\sqrt{ }$ & $\sqrt{ }$ & $\sqrt{ }$ & $\mathrm{x}$ \\
\hline Segíti a szülőkkel való kapcsolattartást & $\sqrt{ }$ & $\mathrm{x}$ & $\mathrm{x}$ & $\mathrm{x}$ \\
\hline Emlékezteti a tanulót a feladataira & $\mathrm{x}$ & $\sqrt{ }$ & $\sqrt{ }$ & $\mathrm{x}$ \\
\hline $\begin{array}{l}\text { Lehetővé teszi a tartalmak egymás között való } \\
\text { megosztását a tanulók számára }\end{array}$ & $\sqrt{ }$ & $\sqrt{ }$ & $\sqrt{ }$ & $\sqrt{ }$ \\
\hline A tanár leosztályozhatja vele a tanulók munkáját & $\sqrt{ }$ & $\sqrt{ }$ & $\sqrt{ }$ & $\sqrt{ }$ \\
\hline $\begin{array}{l}\text { A programba feltölthető: szöveges dokumen- } \\
\text { tum, kép, videó, prezentáció }\end{array}$ & $\sqrt{ }$ & $\sqrt{ }$ & $\sqrt{ }$ & $\mathrm{x}$ \\
\hline Legjelentősebb funkciója & $\begin{array}{l}\text { Tanulók motivá- } \\
\text { lása a napi szintek } \\
\text { elérésével, szülők } \\
\text { értesítése. }\end{array}$ & $\begin{array}{l}\text { Kapcsolattartás } \\
\text { diák-diák és } \\
\text { tanár-diák kö- } \\
\text { zött, anyagok } \\
\text { megosztása. }\end{array}$ & $\begin{array}{r}\text { Oktató } \\
\text { anyagok } \\
\text { megosztása, } \\
\text { feladatok } \\
\text { beadása. }\end{array}$ & $\begin{array}{l}\text { Tanítói } \\
\text { asszistens. }\end{array}$ \\
\hline
\end{tabular}




\section{Irodalom}

Kárpáti, A., Szálas, T., Kuttner, Á. (2012). Közösségi média az oktatásban. Facebookesettanulmányok. Iskolakultúra 22, (10.). 11-42.

Mező, F. (2011). Tanulás: diagnosztike és fejlesztés az IPOO-modell alapján. Debrecen: $\mathrm{K}+\mathrm{F}$ stúdió $\mathrm{Kft}$.

Molnár, Gy. (2011). Az információs-kommunikációs technológiák hatása a tanulásra és oktatásra. Magyar Tudomány, 172, (9). 1038-1047.

Poore, M. (2015). Hogyan használjuk a közösségi médiát az. oktatásban? Budapest: Wolters Kluwer Kiadó.

Prensky, M. (2001). Digital natives, digital immigrants. On the horizon MCB University Press, Vol. P, 5. 1-6.

Tari, A. (2011). Z generáció, Budapest: Tercium Kiadó.

\section{Internetes bivatkozások:}

Chaykowski, K. (2017). How ClassDojo Built One Of The Most Popular Classroom Apps By Listening To Teachers. Forbes. (Letöltés: 2018. december 19.)

Web: https://www.forbes.com/sites/kathleenchayko wski/2017/05/22/how-classdojo-built-one-ofthe-most-popular-classroom-apps-by-listeningto-teachers/\#216fd2871e5e).

Google Classroom. APKMirror. (Letöltés: 2018. december

19.)

(Web: https://www.apkmirror.com/apk/googleinc/classroom/).

Kahn, Jordan (August 12, 2014). Google Classroom now available to all Apps for Education users, adds collaboration features. 9to5Google. - (Letöltés: 2018. december 19.) (Web: https://9to5google.com/2014/08/12/googleclassroom-now-available-to-all-apps-foreducation-users-adds-collaboration-features/).

Lardinois, F. (2016). Google says its G Suite for Education now has $70 \mathrm{M}$ users. techcrunch.com. (Letöltés: 2018. december 19.) (Web: https://techcrunch.com/2017/01/24/googlesays-its-g-suite-for-education-now-has-70musers/?guccounter $=1$ ).

Manage teaching and learning with Classroom. edu.google.com. (Letöltés: 2018. december 19.) (Web:

https://edu.google.com/products/classroom/? modal_active=none).

\section{Honlapok}

https://www.classdojo.com/ https://support.apple.com/en-us/HT206151 https://help.apple.com/classroom/mac/1.0/?lang =en-gb\#/cla6d39b9338

https://www.easyclass.com/ 